\title{
EIF1AX wt Allele
}

National Cancer Institute

\section{Source}

National Cancer Institute. EIF1AX wt Allele. NCI Thesaurus. Code C131316.

Human EIF1AX wild-type allele is located in the vicinity of Xp22.13 and is approximately 17 $\mathrm{kb}$ in length. This allele, which encodes eukaryotic translation initiation factor $1 \mathrm{~A}, \mathrm{X}$ chromosomal protein, plays a role in regulating the efficiency of the translation machinery. 